Int. J. Electrochem. Sci., 11 (2016) 9369 - 9378

\title{
Electrochemical Determination of Ternatin in Ternate Grape Fern Herb Based on the Graphene-Au Nanocomposite
}

\author{
Xinyu Wang, Xinhua Fang, Hongnv Gan, Weier Jiang and Min Wu* \\ The Department of Pharmacy, Hangzhou Traditional Chinese Medicine Hospital, Hangzhou, 310000, \\ P.R. China. \\ "E-mail: mingwu_hangzhou@yahoo.com
}

doi: $10.20964 / 2016.11 .17$

Received: 9 August 2016 / Accepted: 13 September 2016 / Published: 10 October 2016

\begin{abstract}
A simple and effective electrochemical sensor with the electrode modified with RGO/Au (reduced graphene oxide-gold nanoparticle) nanocomposite was developed for the determination of ternatin. Microwave assisted approach was used for the preparation of RGO and then the RGO/Au was obtained by the electrodeposition of $\mathrm{Au}$ nanoparticles on RGO surface. Subsequently, electrochemical impedance spectroscopy (EIS) and cyclic voltammetry (CV) were employed for investigating the electrochemical performance of proposed sensor toward the reduction of ternatin. Obviously, the electrochemical activity of ternatin reduction was greatly improved with the employment of $\mathrm{RGO} / \mathrm{Au}$ nanocomposite modified electrode. The linear response range from $2 \mu \mathrm{M}$ to $600 \mu \mathrm{M}$ was obtained on the sensor. In addition, the proposed sensor can be effectively applied to the detection of ternatin in grape fern herb as well.
\end{abstract}

Keywords: Electrochemical Sensor; RGO/Au/GCE; Ternatin; Grape fern herb

\section{$\underline{\text { FULL TEXT }}$}

(C) 2016 The Authors. Published by ESG (www.electrochemsci.org). This article is an open access article distributed under the terms and conditions of the Creative Commons Attribution license (http://creativecommons.org/licenses/by/4.0/). 